\title{
Isolasi Karakterisasi dan Penentuan Kadar Laktalbumin Susu Sapi Fries Holdstein dengan Metode Lowry
}

\author{
Jimmi Copriady*), Johni Azmi, dan Maharani \\ Program Studi Pendidikan Kimia, Fakultas Keguruan dan Ilmu Pendidikan, Universitas Riau, \\ Jalan HR. Soebrantas Km 12,5 Pekanbaru 28293 \\ Diterima 01-05-2010 \\ Disetujui 11-11-2010
}

\begin{abstract}
Lactalbumin is a major protein found in milk which has great function to human body. It is a component of whey protein in milk. Lactalbumin was isolated from cow's milk of Fries Holdstein breed by centrifugation at high speed $9500 \mathrm{rpm}$ and gel filtration chromatography using sephadex G-50 produced Lactalbumin dissolved in Tris buffer solvent. Characterization of Lactalbumin by measuring the UV absorbance spectrum at $240-320 \mathrm{~nm}$ compared with the spectrum of standard Lactalbumin showed maximum peak at the same wavelength, $280 \mathrm{~nm}$. Lactalbumin content in milk determined by Lowry method was about $0,66 \mathrm{mg} / \mathrm{ml}$ in milk or $9,2 \%$ of whey.
\end{abstract}

Keywords: Characterization, Content Determination, Fries Holdstein, Isolation, Lactalbumin

\section{PENDAHULUAN}

Laktalbumin (á-LA) adalah suatu protein (BM 14,2 kDa) yang berikatan dengan $\mathrm{Ca}^{+2}$ dan merupakan salah satu protein utama penyusun protein whey dalam susu sapi. Di dalam susu sapi terkandung protein dengan kadar $30-35 \mathrm{~g} / \mathrm{l}$ (Kim et al., 2002). Protein susu terdiri atas dua kelompok protein utama yakni kasein dan whey. Protein kasein terdiri atas ${\alpha \mathrm{s}_{1}}_{1}$ kasein, $\alpha s_{2}$-kasein, â-kasein, dan $k^{-k a s e i n}$ (Eskin, 1990). Protein whey disusun oleh á-Laktalbumin, â-Laktoglobulin, Immunoglobulin, Serum Albumin, Laktoferin, dan Laktoperoksidase (Kim et al., 2002). Susu sapi mengandung protein yang terdiri atas $80 \%$ kasein dan 20\% whey (Eskin, 1990). Kasein dapat dipisahkan dari whey dengan cara pengendapan pada $\mathrm{pH} 4,6$ dan pemanasan pada suhu $40^{\circ} \mathrm{C}$ (Boyer, 2000). Laktalbumin merupakan komponen protein dominan penyusun protein whey. Kadar laktalbumin adalah $20 \%$ dari whey dan $3,4 \%$ dari total protein susu (Swaisgood, 1995).

Fungsi biologis Laktalbumin adalah sebagai komponen penyusun enzim laktosa sintase yang berperan dalam biosintesis laktosa di dalam susu (Brew et al., 1967). Laktalbumin dapat berfungsi apoptosis atau antitumor (Fast et al., 2004), antikanker, antibakteri dan antivirus (Svensson et al., 1999).

\footnotetext{
*Telp: +62811767826

Email : jimmi@unri.ac.id
}

Laktalbumin kaya akan asam amino esensial triptofan yang bermanfaat untuk perkembangan otak bayi (Fernstrom, 2005). Manfaat Laktalbumin yang cukup besar bagi tubuh menimbulkan minat para ahli untuk mengisolasinya. Isolasi Laktalbumin dari susu sapi yang telah dilakukan para ahli memperoleh Laktalbumin dengan kadar 1,2 g/l (Konrad \& Kleincsmith, 2007), $1 \mathrm{mg} / \mathrm{ml}$ (Boyer, 2000), 1-1,5 g/l (Swaisgood, 1995) dan 0,6-1,7 g/l (Kim et al., 2000). Sebagai salah satu komponen protein dalam susu, maka kadar laktalbumin tergantung kepada jumlah total protein di dalam susu. Jumlah total protein susu berbeda untuk tiap jenis sapi (Eskin, 1990). Selain faktor jenis sapi, kadar Laktalbumin juga dipengaruhi oleh pakan dan lingkungan. Penelitian Regester dan Smithers, (1991), menunjukkan adanya perbedaan kadar laktalbumin dalam susu sapi pada setiap bulan yang disebabkan oleh perubahan musim. Faktor lingkungan adalah faktor yang memberikan pengaruh cukup besar terhadap tingkat produksi. Di antara sekian banyak komponen faktor lingkungan yang paling nyata pengaruhnya terhadap sapi perah terutama pada masa laktasi (produksi susu) adalah temperatur, yang selalu berkaitan erat dengan kelembaban (Rumetor, 2003).

Salah satu jenis sapi perah yang paling cocok dan menguntungkan untuk dibudidayakan di Indonesia adalah sapi Holdstein (http://www.ristek.go.id). Adapun di Provinsi Riau, telah dibudidayakan peternakan sapi 
perah oleh UPT Ruminansia Besar Dinas Peternakan Kabupaten Kampar. Jenis sapi perah yang dikembangkan adalah Fries Holdstein. Penelitian ini bertujuan untuk mengisolasi, mengetahui karakteristik dan menentukan kadar Laktalbumin dari susu sapi perah jenis Fries Holdstein tersebut.

\section{BAHAN DAN METODE}

Sampel. Susu sapi segar Fries Holdstein diperoleh dari UPT Ruminansia Besar Dinas Peternakan Kabupaten Kampar, Provinsi Riau.Bahan kimia. Sephadex G-50 (Pharmacia), buffer Tris, Bovine Serum Albumin (Germany), $\mathrm{NaOH}, \mathrm{Na}_{2} \mathrm{CO}_{3}, \mathrm{CuSO}_{4} 5 \mathrm{H}_{2} \mathrm{O}$ $0,5 \%$, NaKTartarat $1 \%$, Folin Ciocalteu, Ninhidrin 1\%, $\mathrm{HCl} 1 \mathrm{M}$, dan kertas saring Whatman No.42.Alat-alat. Kolom kromatografi ukuran $300 \times 12 \mathrm{~mm}$, sentrifus kecepatan tinggi (9500 rpm), spektrofotometer UV, kuvet quarzt, pH meter, spektronik 20+D, mikro pipet, hot plate, vortex, buret, dan peralatan lain.

Metode Penelitian. Persiapan Whey. Susu sapi disentrifus pada kecepatan 9500 rpm (dalam keadaan dingin) selama \pm 60 menit, dan didekantasi. Supernatan dan pellet diuji dengan ninhidrin $1 \%$ untuk mengetahui keberadaan protein dominan. $\mathrm{pH}$ supernatan diubah menjadi 4,6 dengan menambahkan tetes demi tetes larutan $\mathrm{HCl} 1 \mathrm{M}$, selanjutnya dipanaskan sampai suhu $40^{\circ} \mathrm{C}$, disentrifus kembali dan didekantasi. Supernatan (whey) disaring dengan kertas whatman no. 42.

Isolasi Laktalbumin. whey $1 \mathrm{ml}$ difraksinasi melalui kromatografi kolom filtrasi gel menggunakan fasa diam sephadex G-50 yang telah diseimbangkan dengan buffer Tris $\mathrm{pH}$ 7. Sebagai eluen adalah buffer Tris $\mathrm{pH}$ 7. Kecepatan aliran $10 \mathrm{ml} / \mathrm{jam}$. Effluent ditampung tiap $2 \mathrm{ml}$ ( \pm 25 fraksi) dalam botol-botol vial. Absorban tiap fraksi diukur dengan spektrofotometer UV pada panjang gelombang $280 \mathrm{~nm}$. Dari hasil pengukuran absorban, diplot grafik nomor vial vs absorban. Sebagai blanko digunakan buffer Tris $\mathrm{pH} 7$.

Karakterisasi Laktalbumin. Fraksi yang mencapai absorban puncak (bukan volume void) dikarakterisasi dengan mengukur spektrum UV pada panjang gelombang $240-320 \mathrm{~nm}$. Spektrum yang diperoleh dibandingkan dengan spektrum Laktalbumin standar yang bersumber dari literatur.

Penentuan Kadar Laktalbumin. Kadar Laktalbumin ditentukan dengan metode Lowry menggunakan larutan standar Bovine Serum Albumin (BSA). Reagen Lowry dibuat dengan melarutkan
$\mathrm{Na}_{2} \mathrm{CO}_{3} 2 \%$ ke dalam $0,1 \mathrm{M} \mathrm{NaOH}$ (reagen $\mathrm{A}$ ), $\mathrm{CuSO}_{4} \cdot 5 \mathrm{H}_{2} \mathrm{O} 0,5 \%$ dalam NaKTartarat $1 \%$ (reagen $\mathrm{B}$ ), reagen $A$ dan $B$ dicampur menjadi reagen $C$, sedangkan reagen folin ciocalteu 2,5 M cukup diencerkan menjadi $1 \mathrm{M}$ (Waterborg, 2002). Larutan standar BSA (1000ì $\mathrm{g} / \mathrm{ml}$ ) dengan 7 konsentrasi yang bervariasi, larutan whey dengan 3 volume yang berbeda dan larutan Laktalbumin (terlarut dalam tris bufer) dengan 3 volume berbeda dipipet ke dalam tabung-tabung reaksi. Ke dalam tiap larutan ditambahkan aquades hingga mencapai volume $1 \mathrm{ml}$. Selanjutnya masing-masing tabung ditambahkan $5 \mathrm{ml}$ reagen $\mathrm{C}$ kemudian diaduk (vortex) hingga homogen. Ke dalam tiap tabung ditambahkan $0,5 \mathrm{ml}$ reagen folin ciocalteu, diaduk (vortex) kembali hingga homogen dan didiamkan pada suhu kamar selama 30 menit. Absorban tiap larutan diukur dengan spektronik $20+D$ pada panjang gelombang $750 \mathrm{~nm}$. Dari pengukuran absorban tiap larutan standar dibuat kurva kalibrasi protein standar sehingga diperoleh persamaan regresi linear $y=a+$ bx dimana $x$ adalah konsentrasi dan y merupakan absorban. Absorban optimum $(>0,5<0,9)$ dari larutan whey dan Laktalbumin disubstitusikan ke dalam persamaan regresi linear untuk menghitung harga $x$ sehingga diperoleh konsentrasi whey dan Laktalbumin. Kadar Laktalbumin diperoleh melalui perhitungan konsentrasi Laktalbumin dibagi konsentrasi whey di kali $100 \%$.

\section{HASIL DAN PEMBAHASAN}

Sertrifusa susu pada kecepatan tinggi 9500 rpm menyebabkan terjadinya pengendapan sel, inti sel, dan organela sel sedangkan lemak berada di permukaan. Makromolekul protein terlarut dalam supernatan. Hal ini ditunjukkan dengan uji ninhidrin yang memperlihatkan warna ungu pada supernatan lebih kuat daripada pellet (gabungan lemak dan endapan). Protein susu dipisahkan menjadi dua kelompok protein besar yakni kasein dan whey. Kasein diendapkan dengan cara pengubahan $\mathrm{pH}$ supernatan menjadi 4,6 (dengan menambahkan $\mathrm{HCl} 1 \mathrm{M}$ ) dan pemanasan pada suhu $40^{\circ} \mathrm{C}$ karena titik isoelektrik kasein diketahui dengan pasti yakni 4,6 dan tidak tahan panas (Poedjadi, 1994). Supernatan sisa disebut whey berupa cairan kental berwarna hijau pucat.

Isolasi laktalbumin dari whey dilakukan dengan metode kromatografi kolom filtrasi gel (sephadex G-50) dengan eluen buffer Tris pH 7. Absorban tiap fraksi 
diukur pada panjang gelombang $280 \mathrm{~nm}$ untuk mengetahui pada fraksi mana terdapat protein. Hal ini disebabkan protein pada umumnya menyerap cahaya pada panjang gelombang $280 \mathrm{~nm}$ karena adanya residu asam amino triptofan, fenilalanin, dan tirosin (Boyer, 2000). Kurva absorban fraksi-fraksi hasil kromatografi kolom filtrasi gel pada panjang gelombang $280 \mathrm{~nm}$ dengan spektrofotometer UV ditunjukkan pada Gambar 1.

Kurva serapan tiap fraksi menunjukkan fraksi yang mencapai absorban tertinggi (yang disebut fraksi puncak) pada vial 13 dan 14. Sedangkan fraksi ke 6 dan 7 berada pada volume void. Gel yang digunakan yakni sephadex G-50 mempunyai batas maksimum berat molekul 30kDa. Molekul yang memiliki $\mathrm{BM}>30 \mathrm{kDa}$ akan keluar bersama pelarut di awal proses kromatografi tanpa mengalami proses pemisahan oleh gel (Boyer, 2000). Komponen molekul protein penyusun whey yang memiliki $\mathrm{BM}>30 \mathrm{kDa}$ adalah Immunoglobulin (150kDa), Laktoferin (94kDa), Serum Albumin (67kDa), dan Laktoglobulin (dimer 36,8kDa) (Martino et al., 2002). Hal ini ditandai dengan adanya puncak pertama (fraksi 6 dan 7) di awal kromatografi (Gambar 1) yang terdapat pada volume void. Protein yang terkonsentrasi pada fraksi 6 dan 7 diduga adalah kumpulan protein dengan $\mathrm{BM}>30 \mathrm{kDa}$. Rentang berat molekul yang

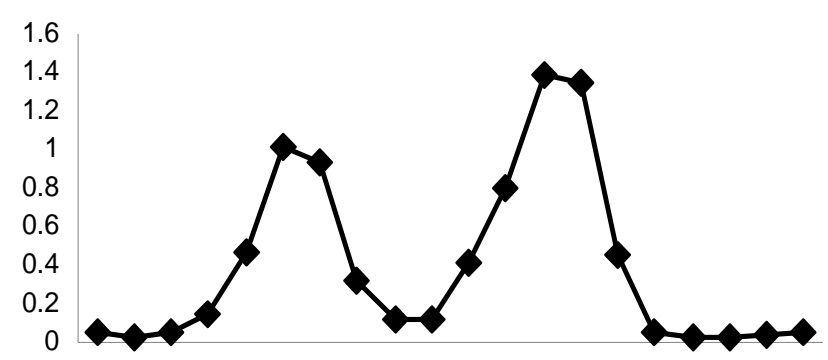

$122 \quad 3 \quad 4 \quad 5 \quad 6 \quad 7 \quad 8 \quad 9 \quad 1011121314151617181920$

$$
\Delta
$$$$
\text { Fraksi-fraksi protein }
$$

Gambar 1. Kurva absorban UV fraksi-fraksi hasil kromatografi kolom filtrasi gel

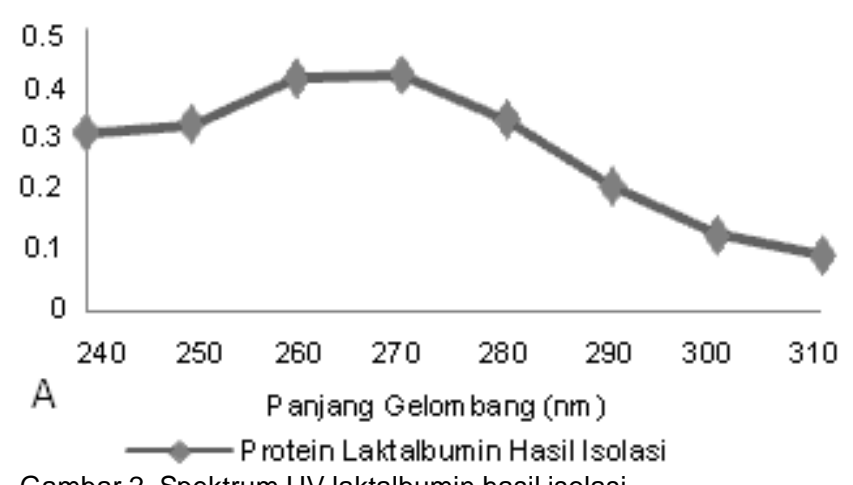

Gambar 2. Spektrum UV laktalbumin hasil isolasi dipisahkan oleh sephadex G-50 adalah 1,5-30 kDa (Boyer, 2000). Molekul penyusun whey yang yang memiliki BM berada dalam rentang tersebut adalah Laktalbumin (14,2kDa) (Martino et al., 2002). Hal ini ditandai dengan adanya puncak setelah volume void (fraksi ke 13 dan 14) yang disebut fraksi puncak. Protein yang terkonsentrasi pada fraksi puncak diduga adalah Laktalbumin. Laktalbumin diperoleh dalam keadaan parsial murni (terlarut dalam pelarut buffer Tris).

Karakterisasi fraksi puncak dengan mengukur spektrum absorban UV pada 240 -320nm ditunjukkan pada Gambar 2, dibandingkan dengan spektrum laktalbumin standar yang ditunjukkan pada Gambar 3. Spektrum UV yang diperoleh (Gambar 2) dibandingkan dengan spektrum UV Laktalbumin standar (Gambar 3) menunjukkan puncak pada panjang gelombang yang sama yakni pada panjang gelombang $280 \mathrm{~nm}$. Karakteristik ini memperkuat kesimpulan bahwa laktalbumin diperoleh pada fraksi puncak.Penentuan kadar whey dan Laktalbumin dilakukan dengan metode Lowry yakni menggunakan kurva protein standar dari larutan standar BSA $1000 \mu \mathrm{g} / \mathrm{ml}$ (Gambar 4). Persamaan regresi linear yang diperoleh adalah $y$ $=0,135+1,085 x$ dimana y adalah nilai absorban dan $\mathrm{x}$ merupakan konsentrasi. Absorban optimum yang berada pada kisaran nilai $>0,5<0,9$ dari larutan whey yang ditunjukkan pada Gambar 5 dan larutan laktalbumin yang ditunjukkan pada Gambar 6 disubstitusikan ke persamaan regresi linear dari kurva kalibrasi standar.

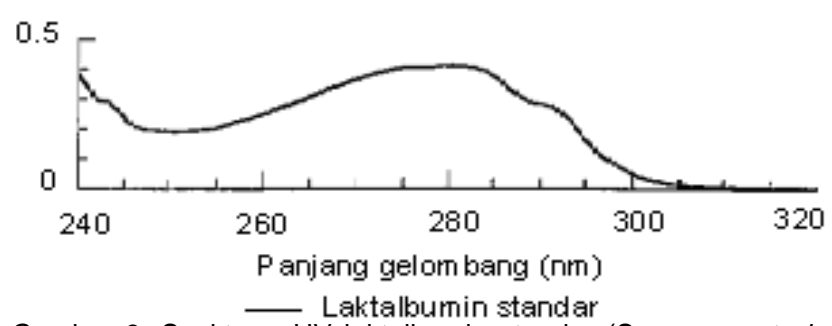

Gambar 3. Spektrum UV laktalbumin standar (Svensson et al., 2002)

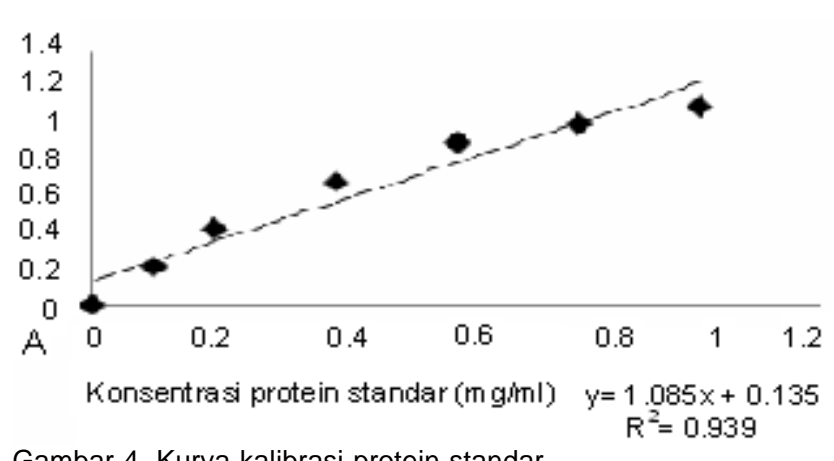

Gambar 4. Kurva kalibrasi protein standar 


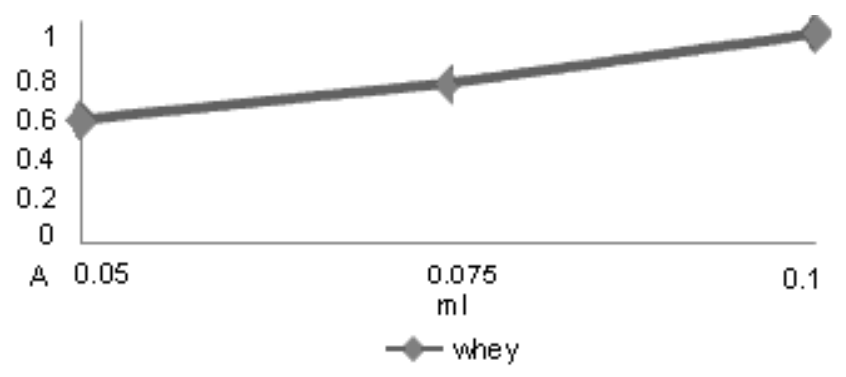

Gambar 5. Kurva absorban whey

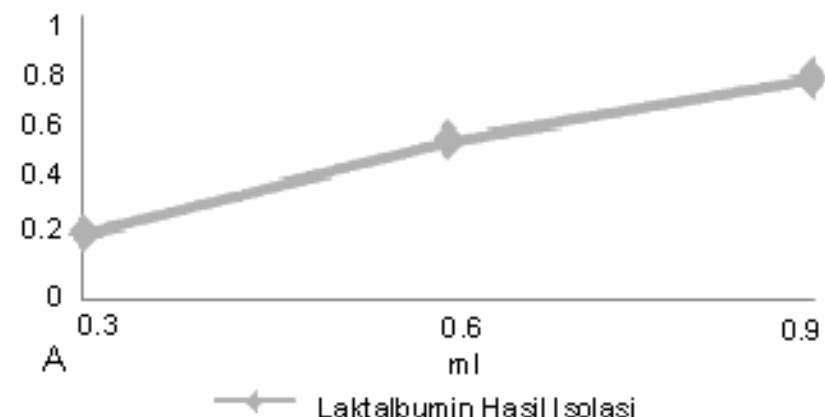

Gambar 6. Kurva absorban laktalbumin

Nilai absorban optimum whey yakni 0,72 pada volume $0,075 \mathrm{ml}$ dan laktalbumin 0,78 pada volume $0,9 \mathrm{ml}$ disubstitusikan ke persamaan regresi linear diperoleh konsentrasi whey $7,18 \mathrm{mg} / \mathrm{ml}$ dan konsentrasi Laktalbumin sebesar $0,66 \mathrm{mg} / \mathrm{ml}$, sehingga kadar Laktalbumin adalah $9,2 \%$ dari total whey. Konsentrasi laktalbumin dari susu sapi yang diperoleh sebesar $0,66 \mathrm{mg} / \mathrm{ml}$ lebih kecil dari konsentrasi laktalbumin dalam susu sapi pada umumnya yakni $1 \mathrm{mg} / \mathrm{ml}$ (Boyer, 2000). Hal ini dapat disebabkan oleh metode Lowry yang digunakan memiliki sensitifitas sedang $(5 \mu \mathrm{g})$ dan tidak sebaik Bradford $(1 \mu \mathrm{g})$ atau BCA $(1 \mu \mathrm{g})$. Hal ini menyebabkan pembacaan absorban tidak sempurna sehingga perolehan konsentrasi kurang akurat.

\section{KESIMPULAN}

Isolasi Laktalbumin dari susu sapi perah jenis Fries Holdstein dengan metode sentrifus dan kromatografi kolom filtrasi gel menggunakan gel Sephadex G-50 diperoleh Laktalbumin dalam keadaan parsial murni yakni terlarut dalam pelarut buffer Tris dan berupa cairan bening agak pekat. Karakterisasi Laktalbumin dengan spektrofotometer UV pada panjang gelombang 240 - $320 \mathrm{~nm}$ menunjukkan absorban maksimum pada panjang gelombang $280 \mathrm{~nm}$. Spekrum absorban UV laktalbumin isolasi dibandingkan dengan spektrum absorban UV Laktalbumin standar menunjukkan puncak pada panjang gelombang yang sama. Penentuan kadar dengan metode Lowry memperoleh konsentrasi whey sebesar $7,18 \mathrm{mg} / \mathrm{ml}$ dan konsentrasi Laktalbumin sebesar $0,66 \mathrm{mg} / \mathrm{ml}$ (9,2\% dari whey).

\section{UCAPAN TERIMA KASIH}

Penulis mengucapkan terima kasih yang sebesarbesarnya kepada Dekan Fakultas Keguruan dan IImu Pendidikan Universitas Riau, Laboratorium Pendidikan Kimia Universitas Riau, Laboratorium Biokimia FMIPA Universitas Riau dan Laboratorium Penelitian Sekolah Tinggi Ilmu Farmasi Riau atas dukungan serta penggunaan fasilitas laboratorium bagi penulis dalam melaksanakan penelitian ini.

\section{DAFTAR PUSTAKA}

Ahmad, R. \& Kadhum, A.H. 1992. Kaedah Pemisahan. Kuala Lumpur : Dewan Bahasa dan Pustaka Kementrian Pendidikan Malaysia.

Barbana, et al. 2004. Interaction of Bovine a Lactalbumin with Fatty Acid as Determined by Partion Equilibrium and Fluoresence Spectroscopy. International Dairy Journal 16: $18-25$.

Boyer, R.F. 1993. Modern Experimental Biochemistry. California : Cumming Publishing Company.

Boyer, R.F. 2000. Modern Experimental Biochemistry. San Fransisco : Addison Wesley Longman.

Brew, et al. 1967. The Role of Alpha-Lactalbumin and the A Protein in Lactose Synthetase : A Unique Mechanism for the Control of A Biological Reaction. Department of Biochemistry Duke University Medical Center, Durham, North Carolina 59: 491-497.

Chatteron, et al. 2006. Bioactivity of â-laktoglobulin and alakatalbumin-Technological Implication for Processing. Internation Dairy Journal 16: 1229-1240.

Eskin, M. 1990. Biochemistry of Food, London : Academic Press.

Fast, et al. 2004. Stability of HAMLET, kinetically trapped álactalbumin oleic acid. Protein Science 14: 329-340.

Fernstrom. The Importance of Tryptophane, http:// www. vitalnews.com.

Holme. \& Peck. 1993. Analytical Biochemistry, New York : Longman Scientific and Technical.

Kim, J, et al. 2002. Separation of Whey Protein by Anion Exchange Membrane. Korean Journal Chem Eng 20(3): 538-541.

Konrad,G \& Kleincsmith, T. 2007. A New Method for Isolation of Native á Lactalbumin from Sweet Whey. International Dairy Journal 18: 47-54.

Martino,R. et al. 2002. Multi-elemental fractionation in milk whey by size exclusion chromatography coupled on line ICP-MS. Journal Anal.At.Spectrom 17: 1271-1277.

Menegristek Bidang Pendayagunaan., Pemasyarakatan IImu Pengetahuan. \& Teknologi. Budidaya Ternak Sapi Perah (1-10). http:www.ristek.go.id.

Peodjadi, A. 1994. Dasar-dasar Biokimia, Jakarta : UI Press.

Regesthers. \& Smithers. 1991. Seasonal Changes in the âLactoglobulin, á-Lactalbumin, Glycomacropeptide, and Casein Content of Whey Protein Concentrate. Dairy Science 74(3): 796-802.

Svensson, M, et al. 1998. Moleculer Characterization of aLactalbumin Folding Varians that Induced Apoptosis in Tumor Cells. The Journal of Biological Chemistry 274(10): 63886396.

Swaisgood. 1996. Milk Proteins, http:// www.Milk2.htm struktur laktalbumin.htm.

Waterborg, J. 2002. The Lowry Method for Protein Quantification from The Protein Protocols Handbook. Biomedical and Life Sciences 1: 7-9. 